\title{
Structuring an Action Net of Public Library Membership
}

\author{
Mary F. Cavanagh
}

ABSTRACT

This article introduces a theoretical framework for conceptualizing public library membership and belonging as an ongoing action net of joint intention and collective action between individual members of the public and the library. It provides an analysis of how membership is constituted, observed, and documented by public libraries from a social-constructivist perspective. Drawing on social theory and philosophy, organizational studies, and secondary public library data sources, a high-level typology of public library member categories from the political and organizational modes of public library action is proposed. Member types are characterized using institutionalized structures of public library use, access, data, discourse, behavior, and social media applications. Implications of this framework for future research and public library innovation are suggested in conclusion.

“W he most important part of public libraries isn't the library, it's the public" (Sparling 2014). What does it mean to be a member of or to hold membership in the organized collective of action that is the contemporary public library? This article examines the idea of the public library from the perspective of its public that is constituted and regulated in some way through the agencies, structures, and practices of membership. Complementing what we know about library-user interactions, this analysis probes what it means to participate in the library's collective action as it is mediated through the sociomateriality of membership (Latour 2005; Leonardi 2012).

Lankes (2011) emphasizes the importance of the relationship between a library and its participants, noting that it must be understood as a relationship of shared ownership and facilitation and not simply a transactional relationship between provider and user or between vendor and customer. He asks and then answers this rhetorical question: "Is the library, to put this in a political context, an institution of the people or for the people?" "If you are for the people, ... you have users and customers, not members. If, in contrast, you feel as I do that the library is of the people, then ... you have members" (66).

The author would like to acknowledge the valuable feedback provided by an anonymous reviewer.

Library Quarterly: Information, Community, Policy, vol. 85, no. 4, pp. 406-426. (C) 2015 by The University of Chicago. All rights reserved. 0024-2519/2015/8504-0005\$10.00

406 
This article is not a critical analysis of the terminology used in research and practice to refer to library participants (e.g., user or nonuser, customer or client), as that is an ongoing question in public library research (Nguyen, Partridge, and Edwards 2012). Nor is it a study of membership from the perspective of the political economy of public libraries (Stevenson 2011) or the excluded or marginalized members of any library's community, as implied in research on information worlds (Jaeger and Burnett 2010). Instead this article takes a pragmatic sociomaterial approach with the goal of identifying all observable and recorded forms of the public library's membership-in-action where membership is but one way into studying public library participation. In sum, this article introduces a preliminary analysis from a social constructivist perspective of how membership is constituted, observed, and documented by public libraries, suggesting how taking this focus may highlight an understudied research thread and why it matters.

Relevant literature pertaining to public libraries and membership is briefly introduced. A preliminary conceptual discussion of membership and an initial typology of public library membership from a social-constructivist perspective are introduced, followed by a proposal for a conceptual framework and a discussion of how these forms of membership are influencing and contributing to the reshaping of the public library's core institutional identity and suite of programs and services. Suggested topics and questions for further research conclude the article.

\section{Participation as Membership}

Participation has become a critical design feature, marketing strategy, and outcome of the social and informational networks that dominate the Internet. Spillover effects from these networks can also be seen in many aspects of offline human interaction. The "networked individual" is characterized as the "new operating system," displacing an older online/offline distinction in which individual connections are more important than group embeddedness (Rainie and Wellman 2012). Within the social sciences, a growing ecology of participation with few fixed organizational boundaries or rules has also been observed (Fish et al. 2011). Traditional distinctions between "organizations" and their member "publics" increasingly do not hold up. "Membership is no longer an easily defined category in a society of freelance work, serious amateurs, casualized labor forces, and the ubiquitous need for user accounts and passwords to gain access to any kind of discussion or action with other (geographically distributed) people" (Fish et al. 2011, 161). In addition to user-generated content (Bruns 2008), other forms of online and in-person engagement and social interaction increasingly rely on sociomaterial mediators (Latour 2005), be it enrollment, log-in, subscription, or some form of user registration or identification. What is less clear, however, is whether such forms of participation might also suggest evidence of membership and member relationships.

It is these types of participation, identification, and member practices that will be discussed from the public library's perspective. Although some form of registration or member- 
ship has become increasingly commonplace in tandem with the rise of online interaction, this informational identification is also becoming a common requirement for many social interactions regardless of their online or real-world contexts. Although Putnam (2000) suggests that the historical decline in community-based voluntary membership associated with leisure activities such as "bowling alone" reflects the shift to participation through online communities and networks, others note that online communities are constituted in many different ways, both "real and 'imagined" (Gruzd, Wellman, and Takhteyev 2011, 1313).

Nor have public libraries escaped these changes in forms of participation. Broadly understood, public libraries recognize participation through two primary information structures: one specifically identified through member registration and the other implied through data and their aggregated statistics representing various forms of library use and access within a given period of time. First, library membership has traditionally been conferred and rendered visible through the materiality of a library card confirming the individual's identity and place of residence and, in doing so, authorizing the individual to access the library's collections and services for a prescribed period. A second information structure by which public libraries have recognized participation through library use and access is the organization's framework for collecting and reporting aggregated statistics of output measures such as visits, circulation, information questions answered, or Wi-Fi users (Canadian Urban Libraries Council 2013). Counts of database usage, catalog searches, or blog pages accessed, for example, are assuming increasing attention and recognition for evaluating and planning new services.

This article addresses these questions: What does being a member of a specific collective action that is the public library look like? Who are the publics in the public library? What are their distinguishing characteristics? How are these member characteristics revealed through interaction? What relationship, if any, is there between forms of use and membership? The term public as either noun (e.g., the public) or adjective (e.g., public opinion) is a ubiquitous reference point in many research disciplines (Warner 2005), including library and information science (LIS). This article will examine the program of action associated with the public library's public from the perspective of library membership.

Membership as an idea recognizes the term's political and sociological dimensions connoting citizenship and shared intention and action, respectively. Members are individuals who enact a temporary or sustained collective action through a shared commitment to the organization's purpose, a form of teleological membership, or shared actions with other members (Gilbert 2014). This article adds to previous scholarship in public library philosophy, and to studies of organizing and of information-seeking practices, by suggesting a conceptual framing of the public in the contemporary public library (Osburn 2009) through this focus on membership, belonging, and forms of shared interaction. The results of this analysis may also be relevant to other types of public services, public policy, and government and nongovernmental organizations. 


\section{Public Library Perspective on Membership}

The majority of public library research either directly addresses or indirectly implies various types of relationships with clients, users, customers, patrons, or members. No research could be identified that directly addresses membership or member categories as the main subject of study. Several primary ways library members and library membership have been examined are through relationships of use or access or through broad reference to the library as community place in relationship with its public. Library use and access studies identify members indirectly by their user behaviors and access characteristics, including their sociodemographic data such as age or generation (e.g., Howard 2011; Cavanagh and Robbins 2012), the types of library services they are accessing (e.g., Bertot, McClure, and Jaeger 2008), the particular geographic location of the library that is the subject of the study (e.g., Given and Leckie 2003; Koontz 2007), their uses of library places and spaces (e.g., Aabø and Audunson 2012), and their use of information technologies (e.g., Williams 2012).

A narrower body of public library research addresses topics such as social exclusion, nonusers, or digital divide and access, where membership is implied by barriers to access (e.g., Pateman and Vincent 2010; Real, Bertot, and Jaeger 2014). Scholarship on the political context of public libraries addresses membership through the lens of library history, citizenship, community development, and access and more recently through analyses of the corporatization or commercialization of public libraries and their services (e.g., Buschman 2003; McMenemy 2009; Stevenson 2011). Research on library marketing and the wide array of evaluation studies of library programs and services also suggest that public libraries are valuing, reorganizing, and redesigning programs and services according to user profiles and increasingly large and accessible repositories of market research data (e.g., Rossiter 2008; Matthews 2013).

Finally, policy reports and field studies of community-led librarianship and community engagement (e.g., Sung, Hepworth, and Ragsdell 2013) by both professionals and researchers that look closely at library-community relationships are perhaps the most promising avenue for understanding more about the range and practices of individual public library membership. Belonging, membership, relationship, and engagement are key concepts in this work, though these concepts are studied largely from the perspective of the community and the community agencies that represent these individual members and citizens. In addition to themes from this selected literature, the following membership framework draws on concepts and theories beyond LIS research in the wider field of the social sciences to establish a foundation for study of public library membership as practice.

\section{Conceptualizing Public Library Membership}

This section introduces the core dimensions of a framework outlining the fundamental goaloriented and structuring dimensions of membership as it mediates interaction between the 
public and the library. The framework draws primarily from concepts in organization studies, social theory, and analytic philosophy, including ideas of belonging, joint intention, collective action, cooperation, the mediating role of objects realized through action nets (Czarniawska 2004), and actor networks (Latour 2005). This framework is provisional, introduced as provocation for future fieldwork, critique, and reflection.

The activity of membership is an ongoing process of intentional association with a collective where the shared purpose is known and where actors engage in shared action. Belonging is an outcome of membership in that collective action. From the sociologist's perspective, when an individual intentionally joins a collective action, becoming another member of that shared action, their membership creates a relationship of structural belonging to the social group. To the social psychologist, however, belonging is characterized as the individual's state of relational connection with others involving variable motivations, duration, and intensity (Dunning 2011). Although psychologists tend to view belonging only in a positive light (Walton et al. 2012), scholars from other disciplines equivocate, suggesting that "belonging should not be seen as automatically superior to not belonging" (May 2011, 374). With the public library as the subject of study, this article is grounded in social theory and organization studies and therefore does not address public library membership from the individual's emotional perspective. Membership can thus be defined as an intentional form of interaction in a social group, in this case, the public library, where some form of structured relationship of belonging is an outcome (Gilbert 2006).

\section{The Library as Organizing Action Net}

The public library is the primary agency and organizing field of public library membershipit is the collective to which many individuals, who are also members of the public, belong. In Lankes's (2011) terms, the library is an institutionalized, collective expression of the people. Historically, public libraries have established and organized themselves primarily by place; this specific geographical place has defined eligibility for membership (Buschman and Leckie 2007).

Philosophers agree that joint action-including the collective intentionality definitive of joint actions - is one of the building blocks of social institutions (Gilbert 2006). Theoretically, the essential attributes of the public library as they play a role in constructing membership are: $(a)$ it is a public institution, in the political sense; $(b)$ it has its own agency, in the organizing sense; $(c)$ it is enacted and sustained through constitutive and regulative rules; (d) it has a collective intention or purpose; and $(e)$ it is realized through joint action, including patterns of behavior and discourse (Giddens 1984; Gilbert 2006; Czarniawska 2013).

Barbara Czarniawska's action net provides a conceptual focus for theorizing, observing, and then characterizing the library's membership interactions. From this characterization, we learn more about how the institutionalized public library organizes and changes over time 
and across physical and virtual spaces. We also learn how members of the library's public interact and play a role in organizing the library action net through their various membership roles. Czarniawska (2004) defines an action net as "a way of looking at things, not another ontological element of social reality, at least not yet. Studying action nets means answering a dual question: what is being done, and how does this connect to other things that are being done in the same context? It is a way of questioning that aims at capturing the traces of the past but not permitting them to decide the future; action nets, even strongly institutionalized ones, are constantly remade and renewed" (784). An action net is revealed through processes of imitation and translation such that "connections between and among actions, when stabilized, are used to construct the identities of actors" (Czarniawska 2013, 14). Over time, the library's legislation, organization, history and identity, and its members have stabilized their connections to each other and in doing so have together mutually constructed the library's identity. Library members can be recognized only in the presence of their library; a public library can be recognized only in the presence of its public.

Today a library's collective intention is expressed through its mission statement, which broadly articulates the goal of providing its public with equitable access to a range of materials for a variety of purposes related to lifelong learning and information seeking and use. The Toronto Public Library, for example, addresses its mission to the "people of Toronto" ${ }^{1}$ and speaks of preserving and promoting "universal access to a broad range of human knowledge, experience, information and ideas in a welcoming and supportive environment." The legitimacy of a membership action net is made evident by the coherence of its structuring, by its recognition and affirmation by other actors and networks, and by the prevalence of its institutionalization (Czarniawska 2004).

An action net fuses two distinct modes of action: the political and the organizational modes (Latour 2013) are combined into one ongoing organizing action. The public library is the organization we can point to, in between these modes of action called organizing. "Organizations - the things - are the phantoms that appear when organizing — the mode - disappears" (Latour 2013, 44). In the arrangement of interpretive landmarks, Bruno Latour (2013) situates the organizational mode "under" and the political mode "over" the field of agencies that continuously remakes the public library.

It can be difficult to differentiate or trace an action net in the public library's organizing context because of the library's long history and generally stable organizational identity and program of action over many decades and many geographies. One might even argue that despite all of the changes occurring in contemporary public libraries with the advent of the Internet age, the fundamental idea of the library, including its member relationships, has

\footnotetext{
1. As quoted, "Toronto Public Library (TPL) provides free and equitable access to library services that meet the changing needs of the people of Toronto" (http://www.torontopubliclibrary.ca/content/about-the-library/pdfs/board /meetings/2012/oct16/07_2.pdf).
} 
been and will remain essentially unchanged. And yet historically we know public libraries did not begin as the fully structured, formally legislated enterprises that we recognize today. The contemporary public library's institutional identity emerged through repeated interactions among many actors across time and space. Tracing this emergent identity from an organizing/ organization perspective can call for several approaches. A historical approach to the central public library action net would be similar to a public library genealogy following library actors and interactions backward in time to their origins with mechanics' institutes and nineteenthcentury industrialization and mass print production. As an alternative approach, disentangling and deconstructing the many varied forms of today's widely occurring library-client interactions and connections can suggest how the library is changing and reorienting itself for the future.

To study library participation specifically as one action net is to scrutinize all the ways individuals interact with the library either directly or indirectly, through formal and familiar membership structures or through any of a myriad of informal interactions. We encounter the public library as organization in some form of membership and belonging when, as individuals, we publicly connect and participate, at any point, in any dimension of its vast program of collective action either discursively or behaviorally. This membership program is realized through a combination of both its political and organizational modes of action outlined here. We cannot know with any certainty what the public library of the future will look like nor what role membership might play in that organization's identity. We might imagine, however, that changes to public libraries' fundamental organizing structures, including membership and institutionalized participation, are possible. The following rendering of this membership action net is a preliminary deconstruction of the widest field of actors whose collective actions are simultaneously changing and affirming what these loosely coupled and more-established structures of belonging look like in today's public library organization.

\section{Political Action of Library Membership}

In its political mode, the public library is recognized as a distinct agency and subject performing a single collective action with an overarching intention (King, Felin, and Whetten 2010; Robichaud and Cooren 2013). The library is constituted through its ongoing commitment to enabling intellectual freedom and literacy through equitable access to information and knowledge resources for individuals in all stages of their lives. This program of action, more important to its identity than its similarities with other commercial or governmentfunded informational actions (e.g., educational institutions, book clubs, social movements, or fee-based information services), is unique to the public library.

The political mode enacts the public library membership action net through legislation and regulation and is administered by a governing board or other delegated government authority. This mode of organizing originates in the library's unique raison d'être to serve its 
public whereby opportunity for membership comes first through citizenship in a given political jurisdiction. Although the specific forms of these jurisdictions vary according to political systems (Gilbert 2006), eligibility for public library membership is usually linked to an individual's residency status in a politically defined and geographically bounded jurisdiction. In practice, a wide array of alternatives for membership may also be articulated through local policies and agreements, for example, allowing clients to purchase memberships, although these alternatives usually constitute a relatively small proportion of members.

From their origins to the present day, public libraries have been created and funded "of the people" through legislation; they act "for the people" through delivery of their services. The library's historical roots in "civic librarianship" (Molz and Dain 1999; McCabe 2001) continue to direct its evolution as a network of social spaces and institutions enabling "participatory democracy" (Pateman 1970). Library historians (e.g., Pawley and Robbins 2013) have documented this evolution from a loosely organized action net of materials, readers, and librarians into the current, formally structured organizing mode continuously responding to community demand for accessible, community-led, learning and leisure reading collections, spaces, and services. Notwithstanding the complexities of identifying all types of these jurisdictions, in the broadest terms, the political mode of public library organizing is rooted in citizenship, residency, and a historical tradition oriented as a grassroots community organization responding to its immediate public.

The public library's political mode reveals itself as a sociomaterial practice defined as an "enactment of a particular set of activities that meld materiality with institutions, norms, discourses and other phenomena we typically define as 'social'” (Leonardi 2012, 34). In the public library's organizing context, this political sociomateriality is revealed in the actions, decisions, and political processes that continually keep the library mission articulated, funded, and accessible to its community of citizens.

\section{Organizational Action of Library Membership}

The organizational mode of action includes those sustaining organizing activities that together underwrite and continually organize the library into the institution its public recognizes through each individual interaction. In practice, no single verb inclusively characterizes this day-to-day agency. Two verbs commonly employed to characterize public library action are use and access; in effect, members use and access the library's programs, collections, services, and spaces. The organizational mode of library membership traces these instances of library use and library access. Therefore, where individuals interact with the library through activities related to access and use, forms of membership may also be traced.

Charles B. Osburn refers to the idea of collective action in asserting that the fundamental intention and program of action of the library are to create social order and stability (Osburn 2009, 140). Drawing widely from evolutionary science, sociology, anthropology, and commu- 
nication, the contemporary library is characterized materially as the "social transcript" that is then constituted and enacted as an evolving program of "cultural technology." As a cultural technology, the library and its publics continuously create human experiences characterized as use of and access to the services, programs, and collections of this social transcript (Osburn 2009, 266). These interactions with individual members construct and reproduce, stabilize and order, and change and evolve the public library's social transcript such that we continue to subscribe to the public library as if it has always and will continue to perform as our cultural platform.

Forms of membership and belonging are directly linked to the more- and less-structured interactions these members have with their library and its program of services. For example, individuals may interact with a library through its online technologies (e.g., accessing the website, searching the catalog, or reviewing reading lists) or through its physical spaces (e.g., sitting in a chair or at a study table) without any institutionally formalized relationship. Although log data and web analytics for library websites, their online catalogs, and gate counts can record various user access data such as IP address or frequency of visit to physical libraries, it remains a question whether or not these counts can be regarded as forms of membership. In both of these physical and virtual settings, however, the library as an autonomous organizing agency is engaged in its distinguishing joint action through these specific interactions with these individuals. Are these types of interactions also forms of membership? This question will be addressed in the discussion of types of library membership.

\section{The Individual as Library Member}

Little primary evidence or relevant research was identified suggesting that residents as members of the public acquire their library memberships for the explicitly stated purpose of participating in a shared activity with its corresponding shared purpose expressed as a collective action with agencies known as public library. As noted, no single verb captures the multiple forms of interaction observed or known through the activities by the term public library; discursively the public library is only ever a subject or object. Library users and nonusers typically report their reasons for membership, or alternately for not having membership, by characterizing how they use or do not use the library through their everyday individual, transactional, and informational interactions (Pew Research Center 2013, 2014).

\section{Typology of Public Library Members}

The following discussion outlines the contemporary public library's membership action net and introduces a preliminary typology developed from selected primary and secondary references. Library member interactions that have been observed, reported, or documented, online or in person, and that take a material form through either discourse or behavior are 
represented by the roles presented here. On this evidence, a typology of public library membership that characterizes library members from their institutional perspective is proposed. It is purposively broad and generic, identifying common features across the species of the public library rather than focusing on individual libraries and their local practices. It is limited to types of individual members because the library's underlying mission has been linked to citizenship at the level of the individual.

Data sources that inform and contribute to this analysis include previous research noted earlier; observation and interview data from a large ethnographic study of public library reference service (Cavanagh 2013), the most recently published annual public library statistics (e.g., Canadian Urban Libraries Council [CULC] 2013), an online archive of Canadian public library Twitter interactions, ${ }^{2}$ and membership policies published by CULC member libraries. Intentions, levels of commitment, or beliefs about membership in the public library are only implied by these secondary sources. For each member type introduced, a description follows of how this membership is formed, structured, practiced, and acknowledged by the library; references to evidence of its observed materiality are noted. These types are not mutually exclusive. Individuals may often belong to more than one category at any one time or over an extended period and may move among categories as they access library services at a given moment or life stage.

\section{Political Action and Membership}

There are several forms of interaction by the citizenry within the political mode of action, which suggest forms of connection and library membership that, with one exception, are more informal, occasional, or indirect types than memberships associated with traditional cardholders or library users. As political agents, the citizens constituting the public library's political jurisdiction are also, conceptually and inclusively, "the people" whom Lankes (2011), among others (e.g., Osburn 2009), connects fundamentally to the public library purpose and program of action.

\section{Opinion Holders}

Opinion holders are those individuals who register their opinions publicly about any aspect of their public library or one of its constituent elements on single occasions or on a regular basis (Tarde 1969). A simplistic assertion can be made that all citizens are public library opinion holders, whether those opinions are expressed or not, simply by virtue of being part of the public. However, the library's membership action net organizes centrally through action and in this case through library-individual interactions that can be observed by the library and other members, or through their interactions rendered material through behavior

2. Social-biblio.ca (http://social-biblio.ca) is an open archive of approximately 190 Canadian public library Twitter interactions and analysis. 
or discourse. For example, where public libraries conduct community needs assessments or surveys of their community members on a subject, those individuals who are represented in the aggregated data of such analyses have participated in this political mode of library membership action. Equally, whenever a citizen is asked to record an opinion about his or her library for another organization such as a chamber of commerce or government agency where such data are aggregated and reported, these individuals can also be considered as holding library membership as opinion leaders.

Another way opinion holders can be traced in a public library's membership action net is through their discursive participation in traditional and online social media (e.g., letters to the editor; radio interviews or call-in shows; testimonials or comments on blogs, news stories, etc.) where the library may be the primary agency in the story or event. Opinion holders may or may not also be cardholders, visitors, or social media subscribers or followers and may or may not be personally identifiable. However, in expressing their opinion about some aspect of their library, they are also demonstrating some active commitment to, and participation in, the library's collective purpose and program of joint action.

As the only legislatively appointed officials and also opinion holders, a library's board members are the formally designated members representing their citizenry in the development and delivery of the library's programs and services. These members interact with their library in the political mode, connecting the organization with its political constituents: taxpayers. This form of membership is restricted according to legislative rules; it is the only type of library membership that individuals cannot assume based only on their own intentions. In this regard, it is also the form of membership that, arguably, is structured so as to exert the greatest influence on shaping the library's shared intention and collective action.

\section{Organizational Action and Membership}

\section{Cardholders}

The most widely endorsed and recognized form of library membership is that associated with library cardholders. In this case, individuals qualify to acquire their individual library membership card that enables access to all of the library's collections, programs, and services. Membership rules govern how a person can acquire a card; these rules also refer to the types of documentation required to confirm the individual's identity, age, and in many instances residence. In many jurisdictions, residents are entitled to a library card at minimal or no additional cost beyond what is provided through taxes upon recognized proof of residence and identity. Some public libraries also allow nonresident individuals to acquire a library card by paying an annual subscription fee. All cardholders are required to periodically renew their memberships through repeated presentation of current personal identification and, where applicable, fee renewals. The library's membership policies typically also prescribe under what circumstances a cardholder's membership may be revoked or interrupted, for example, for 
exceeding limits on charges assigned for lost or late materials. Beyond this basic structure for library membership as a cardholder, there is little standardization of rules and regulations structuring this material form of library membership.

Library cardholders' records are maintained manually or in databases associated with the library catalog. The total number of cardholders is typically reported in annual statistics. Cardholders can be differentiated between active and inactive according to the frequency and currency of their interactions. Cardholder interactions are linked to collection use and, in many instances, to use of the library's public Internet access. A library cardholder's unique number is required to borrow materials, to access licensed resources, and to access the library's public Internet services. To recognize a new type of library use, some libraries have begun to offer an Internet-access only card as an alternative to the all-inclusive library card. In all cases, the material representation of membership for each individual is the physical card itself and the unique record of personally identifiable information associated with it.

Visitors

Visitors to public libraries are those individuals who occupy or inhabit a library space for a period of time and who during their visit may (or may not) independently interact with library collections, programs, and services without direct contact with a staff member and without a requirement to produce a library card. Visitors may be further characterized as occupiers, listeners, attendees, or readers based on how they use or access their library at a given moment. As a type of library member, visitors are self-organizing; their membership is enacted and recognized only by their information behaviors, which do not require the permission and personal identification associated with cardholders.

Whereas visitors were previously limited to individuals one could actually see in person, new forms of online visiting can also clearly be observed and are made material, though only as aggregates through site analytics and web logs. A library's website is increasingly characterized as another public library space or digital library alongside physical branches or other branded spaces such as bookmobiles. Such spaces may be visited for longer or shorter durations. Typically no identification or material membership proof is required for these individuals to occupy either library buildings or public spaces or to access the library's core online spaces that are its website and catalog. A distinction must be made between accessing and interacting in the library's online spaces. To scroll the library's website or search the catalog is to access these spaces, whereas to place an item in the catalog on hold is to interact with the library as a cardholder.

Research on library as place (Buschman and Leckie 2007) exposes the myriad of individual and collective activities people have been observed doing in library buildings (Given and Leckie 2003), including such activities as reading, listening to and viewing library materials, accessing the Internet, socializing, attending programs, or accessing information or instruc- 
tional services. Online logs also observe visits to various pages of a library's website. Visitors in either mode may or may not access any formal library services such as reference services or library programs. At a minimum, visitors occupy a library space and place for a period of time without formally identifying themselves.

Physical visitors are usually only randomly observed by staff and fellow occupants, whereas online visitors are rarely observed through their behaviors in the same way. A physical visitor's presence may be recorded through aggregated gate counts of visits where such data are collected, although this is not a standard requirement of many libraries. Online visitors are tracked indirectly and anonymously through log data. Any visitors who access specific library services such as reference services or programs are separately recognized in aggregated counts of those services. Unique visitors are not differentiated from library visits.

A subset of library visitors are those individuals who are known to staff and sometimes to other clients by virtue of the regularity of their interactions, including their use of physical or online library services. Regulars may also be cardholders. Included under this type of membership, for example, would be reference clients who regularly and repeatedly call the reference staff with information questions or clients who use public Internet access and or make in-library use of materials (Cavanagh 2006). Like visitors, but unlike cardholders, this type of library membership is self-organizing. It is defined by barrier-free, repeated access to a library's physical buildings, physical collections and services, and public spaces resulting in some form of shared knowing or recognition by library personnel.

Regulars come both to know and to be known by staff and other members of the public from repeated, occasional or more frequent, interaction. For example, individuals who regularly visit the library to read current newspapers and magazines may be recognized and in this way are often also known by others engaging in the same activity. Individuals who regularly submit requests to purchase new titles for the library's collection can also come to be known to staff by the regularity and frequency of these interactions. Regulars are only formally recognized by the library largely through the source of their interaction rather than necessarily through their identities as individuals except where such disclosure is already required by the interaction. Unlike visitors, regulars are individuals who are typically known to library staff; like visitors, however, regulars are recognized only through counts of library visits.

\section{Outreach Participants}

In many libraries, programs that occur away from library property are considered outreach activities. Public libraries are increasingly diversifying their programming topics, formats, and settings, whether through partnerships with other agencies, expanded use of information and communication technologies, or shifts to embedded professionals in other socialinformational and organizational settings. The question of what type of member relation- 
ships these program attendees or any other outreach activities exhibit is increasingly invited. When a librarian hosts an occasional social book-club event at a neighborhood restaurant, for example, the only material and therefore explicitly durable indication of participation is through having one's name on a preregistration list and a number of attendees reported for statistical purposes. No fee is required, nor is there a requirement to have a library card in order to participate. These participants may never set foot in their local library nor borrow materials nor use any of the library's online services, yet they have made at least some connection with the library through the librarian. This situation suggests an emerging form of library membership that looks more like a social media interaction that is an encounter with a library voice rather than a library visit that is an encounter with a library space.

\section{Social Media Followers and Subscribers}

Social media platforms such as Facebook, Twitter, YouTube, and Pinterest are becoming important public channels through which libraries and members of their publics can interact through discourse and content sharing. Social media membership is constructed predominantly through registration and discourse. Conversation, social signaling, and content sharing interactions structure both a member's connection to the library and the library's connection to its members. Online user profiles can be established with the provision of minimal identification information. From these accounts, participants then choose to identify themselves to others in various ways as followers, community members, friends, or subscribers. In each case, the terminology used by the social media application suggests a particular role and structure to the member's relationship and interaction that is designed into the media platform. For example, subscribing suggests the more commercial interaction associated with commercial video streaming services such as Netflix and also suggests a quite different form of relationship than do the actions of befriending, following, or joining.

Many organizations have identified the benefits of increasing membership through such channels to further expand their organization's reach (Mergel 2013), and public libraries are no exception (Solomon 2011). Libraries have also socialized their primary interaction spaces through the introduction of social catalogs such as BiblioCommons that embed similar types of functions for interacting inside the online public access catalog. Information behaviors associated with these social media depend on the design and structures of the respective channels.

The primary social media platforms used by public libraries are Facebook, Twitter, Google+, YouTube, and Pinterest (Dankowski 2013). To be identified materially as a public library Twitter follower or Facebook community member, for example, is to have one's profile and user identification name visible and associated with a library's account along with those of other followers or community members, regardless of whether or not the member 
posts, comments, or otherwise participates through separate interaction. In this sense to follow, join, or subscribe to a library's social media channel is to create a connection to the library through the specific commercial platform.

These connections constitute a new type of library membership. Social media platforms enable a library and its participant followers and subscribers to engage in both the political and the organizational modes of action simultaneously within the same structured interactions. For example, a member can express an opinion (e.g., "I love my library"), ask an information question (e.g., "Do you have kids' books?"), and engage in social talk (e.g., "Have a great day") within the same structured interaction with their library. Although some platforms allow members the choice to restrict access to their participation interactions, most public libraries keep their social media accounts open and unrestricted. The aggregation of these connections may in some settings, such as the social catalog, also be interpreted by designers and by libraries as constituting an online community (Tarulli 2013). Patterns of frequency and discursive forms of members' interactions can be viewed and tracked over time. However, when members simply view or read interactions in an online community or when they follow a library's Twitter feed, this silent, or "listening" (Crawford 2009), participation cannot be publicly visible, and therefore known, to the library or to other followers or members. Most public libraries have not yet standardized reporting of social media participation in their annual statistical reports.

\section{Proposing a Structure for a Membership Action Net}

Based on the foregoing analysis, the public library's membership action net can be conceptualized and represented graphically as shown in figure 1. A continuously changing field of behavioral and discursive interactions organizes several broad types of individual library membership for which there is observable or documentary material evidence available to the library. As noted, the public library's membership action net is evidenced through both the political and organizational modes of action and discursive and behavioral practices.

Above the field of interaction is the public library's political mode of action, where evidence of joint commitment to and belief in the larger mission and purpose of the library are organized through public participation and legislative processes. The largest and arguably least explicit type of membership is that which comes through citizenship in the political jurisdiction. A subgroup of citizen members is opinion holders consisting of a diverse range and number of individuals who publicly express their opinions and indirectly their beliefs about the library through media, political processes, and library outreach in, for example, referenda, user surveys, or planning consultations. Finally, board members are the politically designated representatives of the citizenry who have deeply institutionalized authority, obligation, and responsibility for articulating and translating the public library's purpose that can be realized through programs and services. 


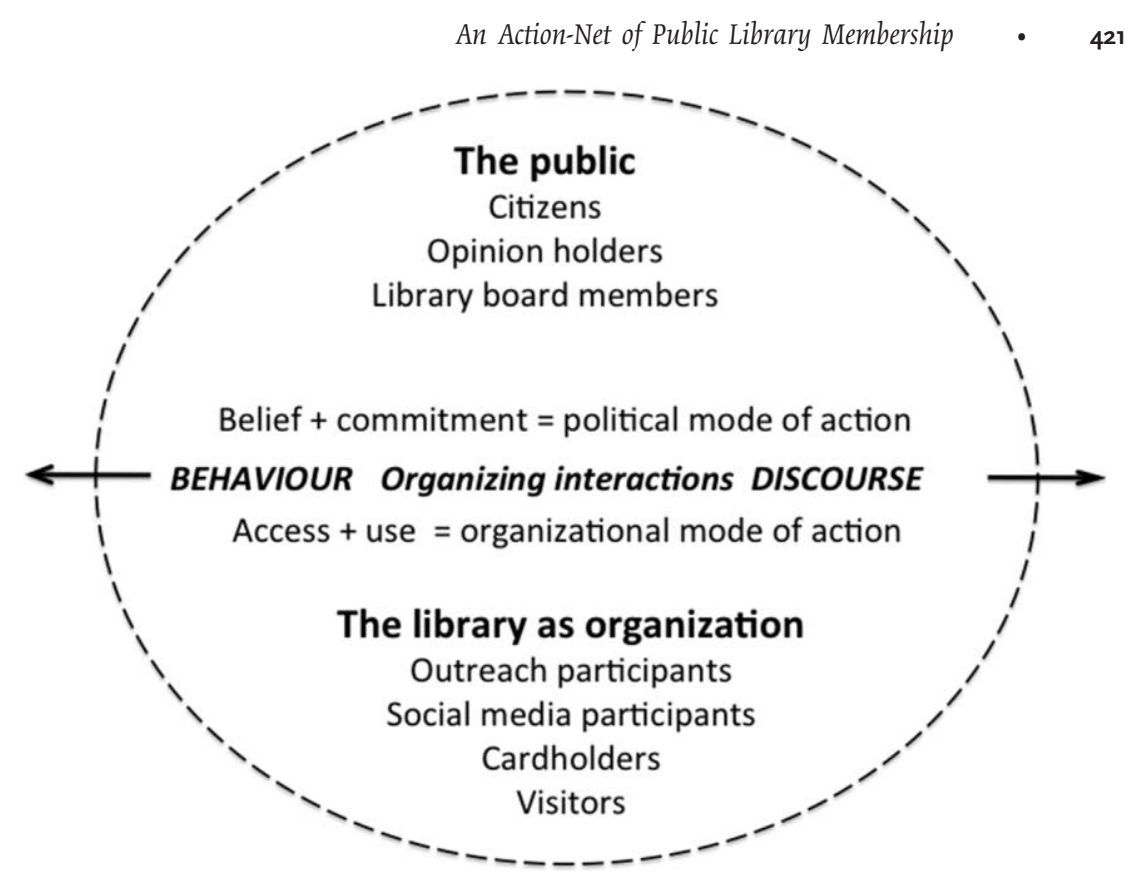

Figure 1. Public library membership action net conceptualized

Below the field of interaction is an organizational mode of action whereby the library's joint purpose is realized through the continuous organizing of its shared program of services, collections, and activities. This program organizes different forms of membership observed and documented primarily through library use and access. Cardholders, like board members, are the most institutionalized, publicly recognized, and best-established type of library member. Cardholders enter into a highly regulated relationship of rules and permissions that authorize and enable their participation in joint library action. Visitors are those types of members whose membership organizes around a variety of behaviors, none of which typically require immediate mediation or regulation by the library of its staff. These activities include occupation and presence in library spaces; in-library listening to, reading, and viewing library materials; and participation in library events and programs. Closely related to the general class of visitors are library regulars who are habitual users known both to staff and to other members and who may or may not directly interact with library staff. Outreach participants are those members whose relationships are mediated primarily by staff in nonlibrary places and space. Finally, social media participants constitute a new form of library member; social media subscribers and followers can interact organizationally and politically simultaneously with the library within the same interaction structures and online spaces.

Public library members are not only those people who at one time have been approved for a library card that they carry in their wallets alongside their customer reward cards and 
bank or credit cards and present to borrow materials from their local library. This has been the traditional, and often still prevalent, characterization of library membership. This analysis suggests that membership is an ongoing process of organizing the public library's public into stronger and weaker, intermittent and sustained relationships of connection, joint purpose, and shared action. Moreover, these organizing processes materialize and are translated through various institutional and informational structures that can be traced only by following the agency action net of library-human interactions.

To identify the political dimensions of public library membership is to recognize that the public library's members are not only those who use or access library services. The library's relationship with its public has been thoroughly acknowledged, at least theoretically, though often only indirectly, through references to the library as Oldenberg's "third place" (Buschman and Leckie 2007) or as part of a Habermasian "public sphere" (Buschman 2003). The conceptualized ideal of the library as a political space does not confer membership on its own. In practice it is the action net of organizing agencies, including discursive actions and interactions among citizens and their library that confer at least a minimal structure of library membership. Through these interactions individuals both construct and express opinions about the library and engage in conversations with their library (Lankes 2011). A library's opinion holders have a specific type of socially constructed political membership that is only loosely, and always provisionally, structured. Opinion holders may or may not ever occupy, visit, use, or otherwise inhabit official library spaces (physical or virtual), yet they hold a membership that is often valued by the library. In expressing their opinions about the library, these members constitute a "specialized public," and, as Warner (2005) notes, "one of the most striking features of publics, in the modern public sphere, is that they can in some contexts acquire agency. Not only is participation understood as active, at the level of the individual whose uptake helps to constitute a public, it is also sometimes possible to attribute agency to the virtual corporate entity created by the space of circulation as a whole. Publics act historically" (122-123). For example, opinions expressed by nonusers identified by a research consulting firm informed the Toronto Public Library's most recent strategic planning process. ${ }^{3}$ Similarly, as part of a larger advocacy action, citizens responded to proposed library closures with a petition of 26,000 signatures (Eberhart 2004). In both cases, these opinion holders can be distinguished as library members by their documented participation in these political processes.

One outcome of the many interactions occurring on social media platforms and through other forms of online participation is the proliferation of data and data sets. From a public library's organizational perspective, user interactions represented as data and gathered in

3. Toronto Public Library refers to opinion holders in its most recent strategic planning consultation process involving commissioned surveys of users and nonusers, social media chats, online forums, and in-library focus groups. Available at http://www.torontopubliclibrary.ca/about-the-library/strategic-plan/consultation.jsp. 
these data sets provide an objective means for tracking changes in use patterns, allowing libraries to rationalize and develop the next organizational innovations on behalf of their entire membership. In agency terms, however, the data themselves also participate in the public library's membership action net as a single actor. To avoid an increasingly narrow interpretation of library membership by representing only their material forms such as data sets or "virtual corporate entities," however, libraries can also find ways to look beyond the data, identifying and acknowledging the human faces and unique individual performances associated with them. To enter into any form of public library membership with its related outcome of belonging is, after all, a singularly human process.

Another aspect of public library membership structures that this analysis highlights is that membership as organizing agency is publicly observed or observable and is somehow documented in information artifacts, whether a cardholder database, a review in a social catalog, or a presence in a library. The role of commercial media platforms in mediating and translating individuals' connections to their library bears scrutiny and further research. The process of becoming a library member is social, has a dimension of materiality, and is constituted through action, interaction, and practice. What this analysis does not address is what effect public library membership has on individuals in their day-to-day lives. Are there psychological dimensions to belonging that might influence how libraries design and integrate digital and physical services to strengthen engagement and relationships with their members? How do these membership structures change and change individuals over time and across their experiences of libraries?

\section{Conclusion and Future Research}

This framework with its provisional typology of public library membership invites further study and reflection, particularly as it bears on belonging as an outcome of membership. What motivations and effects do these types of membership actions have for a library's citizens and public? Building on previous work, this typology might also suggest how such membership decisions might influence a community's social networks and perceived changes in the library's contributions to social capital (Johnson 2012). This membership framework could also assist public agency administrators, library practitioners, and social science researchers, for example, in contextualizing program and organizational evaluation studies, in examining the role of participatory librarianship in public library organizing, or in practical understanding of what community engagement and information relationships consist of in the new age of digital citizenship.

By framing membership as an action net of practices in which humans, objects, other agencies, and institutions commingle, interact, and continually order and organize themselves into different patterns of member behavior and discourse, the emphasis also suggests that public library research shift its perspective slightly, moving from a focus on organizing the 
networked library to a focus on organizing the library in the networked life of the individual. Structuring and therefore valuing membership according to established, library-defined categories of use or access or according to the library's aggregated statistics privileges only those interactions visible from the institutional perspective of the library as organization. This analysis suggests an additional perspective and a framework for applying it. In tracing membership in the public library's member action net by following individual behaviors and discursive library interactions themselves, we get a wider view of how contemporary public library membership organizes all the actors of this action net while simultaneously becoming the next-generation version of the public library.

\section{References}

Aabø, Svanhild, and Ragnar Audunson. 2012. "Use of Library Space and the Library as Place." Library and Information Science Research 34 (2): 138-49.

Bertot, John Carlo, Charles R. McClure, and Paul T. Jaeger. 2008. "The Impacts of Free Public Internet Access on Public Library Patrons and Communities." Library Quarterly 78 (3): 285-301.

Bruns, Axel. 2008. Blogs, Wikipedia, Second Life, and Beyond: From Production to Produsage. New York: Peter Lang.

Buschman, John E. 2003. Dismantling the Public Sphere: Situating and Sustaining Librarianship in the Age of the New Public Philosophy. Westport, CT: Libraries Unlimited.

Buschman, John E., and Gloria Leckie. 2007. The Library as Place: History, Community and Culture. Westport, CT: Libraries Unlimited.

Canadian Urban Libraries Council/Conseil des Bibliothèques Urbaines du Canada. 2013. 2013 Canadian Public Library Statistics. Prepared by Jennifer Marriott for the Canadian Urban Libraries Council (CULC)/ Conseil des Bibliothèques Urbaines du Canada (СBUC). http://www.culc.ca/kpis.

Cavanagh, Mary F. 2006. "Re-conceptualizing the 'Reference Transaction'-the Case for Interaction and Information Relationships at the Public Library Reference Desk." Canadian Journal of Information and Library Sciences $30(1 / 2): 1-19$.

Cavanagh, Mary F. 2013. "Interpreting Reference Work with Contemporary Practice Theory." Journal of Documentation 69 (2): 214-42.

Cavanagh, Mary F., and Wendy Robbins. 2012. "Baby Boomers, Their Elders and the Public Library." Library Review 61 (8/9): 622-40.

Crawford, Kate. 2009. "Following You: Disciplines of Listening in Social Media." Continuum: Journal of Media and Cultural Studies $23(4): 525-35$.

Czarniawska, Barbara. 2004. “On Time, Space, and Action Nets.” Organization 11 (6): 773-91.

Czarniawska, Barbara. 2013. "Organizations as Obstacles to Organizing." In Organization and Organizing: Materiality, Agency and Discourse, edited by Daniel Robichaud and François Cooren. New York: Routledge.

Dankowski, Terra. 2013. "Expanding Online Toolkits to Promote Advocacy." How Libraries Are Using Social Media. July 16. http://www.americanlibrariesmagazine.org/article/how-libraries-are-using-social-media.

Dunning, John, ed. 2011. Social Motivation. New York: Psychology Press.

Eberhart, George M. 2004. "Regina PL Board Approves Closures; Friends Vow to Continue Fight." American Libraries 35 (5): 20. 
Fish, Adam, Luis F. R. Murillo, Lilly Nguyen, Aaron Panofsky, and Christopher M. Kelty. 2011. "Birds of the Internet: Towards a Field Guide to the Organization and Governance of Participation" Journal of Cultural Economy 4 (2): 157-87.

Giddens, Anthony. 1984. The Constitution of Society. Los Angeles: University of California Press.

Gilbert, Margaret. 2006. A Theory of Political Obligation: Membership, Commitment, and the Bonds of Society. Oxford: Oxford University Press.

Gilbert, Margaret. 2014. Joint Commitment: How We Make the Social World. Oxford: Oxford University Press.

Given, Lisa M., and Gloria J. Leckie. 2003. "'Sweeping' the Library: Mapping the Social Activity Space of the Public Library." Library and Information Science Research 25 (4): 365-85.

Gruzd, Anatoliy, Barry Wellman, and Yuri Takhteyev. 2011. "Imagining Twitter as an Imagined Community." American Behavioral Scientist 55 (10): 1294-318.

Howard, Vivian. 2011. "What Do Young Teens Think about the Public Library?" Library Quarterly 81 (3): 32144 .

Jaeger, Paul T., and Gary Burnett. 2010. Information Worlds: Social Context, Technology, and Information Behavior in the Age of the Internet. New York: Routledge.

Johnson, Catherine A. 2012. "How Do Public Libraries Create Social Capital? An Analysis of Interactions between Library Staff And Patrons." Library and Information Science Research 34 (1): 52-63.

King, Brayden G., Teppo Felin, and David A. Whetten. 2010. "Finding the Organization in Organizational Theory: A Meta-Theory of the Organization as Social Actor." Organization Science 21 (1): 290-305.

Koontz, Christie M. 2007. "A History of Location of U.S. Public Libraries within Community Place and Space: Evolving Implications for the Library's Mission of Equitable Service." Public Library Quarterly $26(1 / 2): 75-100$.

Lankes, R. David. 2011. The Atlas of New Librarianship. Cambridge, MA: MIT Press.

Latour, Bruno. 2005. Reassembling the Social: An Introduction to Actor-Network Theory. Oxford: Oxford University Press.

Latour, Bruno. 2013. "What's the Story? Organizing as a Mode of Existence." In Organization and Organizing: Materiality, Agency and Discourse, edited by Daniel Robichaud and François Cooren. New York: Routledge.

Leonardi, Paul. 2012. "Materiality, Sociomateriality, and Socio-Technical Systems: What Do These Terms Mean? How Are They Different? Do We Need Them?" In Materiality and Organizing: Social Interaction in a Technological World, edited by Paul Leonardi, Bonnie A. Nardi, and Jannis Kallinikos. Oxford: Oxford University Press.

Matthews, Joseph R. 2013. Research-Based Planning for Public Libraries: Increasing Relevance in the Digital Age. Santa Barbara, CA: Libraries Unlimited.

May, Vanessa. 2011. "Self, Belonging and Social Change." Sociology 45 (3): 363-78.

McCabe, Ronald. 2001. Civic Librarianship: Renewing the Social Mission of the Public Library. Lanham, MD: Scarecrow Press.

McMenemy, David. 2009. The Public Library. London: Facet Publishing.

Mergel, Ines. 2013. Social Media in the Public Sector: A Guide to Participation, Collaboration and Transparency in the Networked World. San Francisco, CA: Jossey-Bass.

Molz, Kathleen, and Phyllis Dain. 1999. Civic Space/Cyberspace: The American Public Library in the Information Age. Cambridge, MA: MIT Press.

Nguyen, L. C., Helen Partridge, and S. L. Edwards. 2012. "Towards an Understanding of the Participatory Library." Library Hi Tech 30 (2): 335-46. 
Osburn, Charles B. 2009. The Social Transcript: Uncovering Library Philosophy. Westport, CT: Libraries Unlimited. Pateman, Carole. 1970. Participation and Democratic Theory. Cambridge: Cambridge University Press.

Pateman, John, and John Vincent. 2010. Public Libraries and Social Justice. Surrey, UK: Ashgate Publishing.

Pawley, Christine, and Louise S. Robbins. 2013. Libraries and the Reading Public in Twentieth-Century America. Madison: University of Wisconsin Press.

Pew Research Center. 2013. "How Americans Value Public Libraries in Their Communities." http://libraries .pewinternet.org/2013/12/11/libraries-in-communities.

Pew Research Center. 2014. "From Distant Admirers to Library Lovers: A Typology of Public Library Engagement in America." http://libraries.pewinternet.org/2014/03/13/typology.

Putnam, Robert. 2000. Bowling Alone: The Collapse and Revival of American Community. New York: Simon \& Schuster.

Rainie, Lee, and Barry Wellman. 2012. Networked: The New Social Operating System. Cambridge, MA: MIT Press.

Real, Brian, John Carlo Bertot, and Paul T. Jaeger. 2014. "Rural Public Libraries and Digital Inclusion: Issues and Challenges." Information Technology and Libraries 33 (1): 6-24.

Robichaud, Daniel, and François Cooren, eds. 2013. Organization and Organizing: Materiality, Agency and Discourse. New York: Routledge.

Rossiter, Nancy. 2008. Marketing the Best Deal in Town: Your Library: Where Is Your Purple Owl? Oxford: Chandos.

Solomon, Laura. 2011. Doing Social Media So It Matters: A Librarian's Guide. Chicago: American Library Association.

Sparling, Allison. 2014. "I Hang Out at Libraries, Even When I'm Not Looking for a Book." The Coast, Voice of the City, March 20. http://thecoast.ca/halifax/i-hang-out-at-libraries-even-when-im-not-looking-for -a-book/Content?oid=4294502.

Stevenson, Siobhan. 2011. "New Labour in Libraries: The Post-Fordist Public Library." Journal of Documentation 67 (5): 773-90.

Sung, Hui-Yun, Mark Hepworth, and Gillian Ragsdell. 2013. "Investigating Essential Elements of Community Engagement in Public Libraries: An Exploratory Qualitative Study." Journal of Librarianship and Information Science 45 (3): 206-18.

Tarde, Gabriel. 1969. On Communication and Social Influence: Selected Papers, edited by Terry N. Clark. Chicago: University of Chicago Press.

Tarulli, Laurel. 2013. The Library Catalogue as Social Space: Promoting Patron Driven Collections, Online Communities and Enhanced Reference and Readers' Services. Santa Barbara, CA: Libraries Unlimited.

Walton, Gregory M., Geoffrey Cohen, David L. Cwir, and Steven J. Spencer. 2012. "Mere Belonging: The Power of Social Connections." Journal of Personality and Social Psychology 102 (3): 513-32.

Warner, Michael. 2005. Publics and Counterpublics. Brooklyn, NY: Zone Books.

Williams, Kate. 2012. "Informatics Moments." Library Quarterly 82 (1): 47-73.

Mary F. Cavanagh: associate professor at the School of Information Studies, University of Ottawa. Cavanagh takes a practice-based approach to understanding and interpreting innovation and change in information organizations with particular focus on public libraries. She explores questions related to sociality, forms of organizing, and information interaction through shared knowing, learning, and participation, particularly across citizen-public institutional boundaries. Current projects include an exploration of microblogging practices in public libraries and a framework of current measures used to assess value of public libraries in their communities. E-mail: mcavanag@uottawa.ca. 